\title{
Comparison of HTLV-associated myelopathy (HAM) in HIV-positive and HIV-negative patients at a tertiary South African hospital
}

\author{
C-M Schutte, T Townsend, R Van Coller, S Olorunju \\ Department of Neurology, Steve Biko Academic Hospital, Pretoria \\ C-M Schutte, M Med (Neurol), MD \\ T Townsend, M Med (Neurol),FCN \\ R Van Coller, M Med (Neurol) \\ Medical Research Council, Pretoria \\ S Olorunju, $\mathrm{PhD}$ \\ Corresponding author: C-M Schutte (cschutte@meic.up.ac.za)
}

\begin{abstract}
Background. HTLV-1 associated myelopathy (HAM), or tropical spastic paraparesis, is caused by a retrovirus, the human T-cell lymphotropic virus (HTLV). Although patients with HAM and HIV infection have been described, to our knowledge no direct comparison has been made between patients who are HIV positive and suffering from HAM (HHAM) v. those who are HIV negative and suffering from HAM.

Aim. We aimed to compare clinical and radiological findings in HIV-positive and -negative patients with HAM.

Methods. Adult patients who presented to the Neurology Unit at the Steve Biko Academic Hospital from May 2005 to June 2012 with a progressive myelopathy and HTLV seropositivity were retrospectively identified and their clinical and radiological data were collected and reviewed.

Results. 21 patients with HAM were identified, of whom 9 were HIV-positive and 11 HIV-negative. One patient, whose HIV status had not been established, was not included in the study. Although the trend did not reach statistical significance, co-infected patients tended to present at an earlier age (HHAM 6/9 (66\%) <40 years old; HAM 2/11 (18\%) <40 years old) and presented to hospital earlier (HHAM 6/9 $(66 \%)<3$ years symptomatic; HAM 7/11 $(63 \%)>3$ years symptomatic). Cord atrophy occurred in $7 / 8$ dually infected patients and $8 / 10$ HIV-negative patients.

Conclusion. Although the study is limited by the small number of patients, co-infected patients tended to have a younger age of onset and to present to hospital sooner, and thoracic cord atrophy was very common.
\end{abstract}

S Afr Med J 2013;103(1):43-46. DOI:10.7196/SAMJ.5298

Human T-cell lymphotropic virus type-1 (HTLV-1) is a type C retrovirus endemic to tropical areas. Most infected people are asymptomatic carriers, but an estimated $0.25 \%-2 \%$ of carriers develop a progressive myelopathy, known as HTLV-associated myelopathy (HAM) or tropical spastic paraparesis (TSP)., ${ }^{1,2} \mathrm{HTLV}-2$ is more common among intravenous drug abusers, and may present with a clinical picture similar to HAM. ${ }^{2}$

During the last two decades, the HIV pandemic has influenced the spectrum of neurological disorders markedly - up to $40 \%$ of patients with HIV infection clinically show neurological disorders, ${ }^{3}$ and neuropathological abnormalities are even more common. Co-infections of HIV and HTLV- 1 have been described ${ }^{4,5}$ and in South Africa a high prevalence of HAM has been found in KwaZulu-Natal, ${ }^{5}$ with up to $36 \%$ of patients showing HIV co-infection. A study from Brazil reported on patients with HIV and $\mathrm{HAM}^{4}$ but did not directly compare patients with and without HIV infection. 


\section{RESEARCH}

We aimed to evaluate the number of patients with HAM seen at the Neurology Department of the Steve Biko Academic Hospital, a tertiary hospital in Gauteng Province, and to compare the clinical and radiological findings of patients who were co-infected with HIV with those who were HIV negative.

\section{Patients and methods}

Patients were identified retrospectively from a list of patients with positive HTLV-1 serology who presented to the National Health Laboratory Services (NHLS) at the Steve Biko Academic Hospital, from May 2005 to June 2012. To ascertain which of these seropositive patients had presented to the hospital's Department of Neurology, the department's electronic database was consulted. Patients included in the study were those 13 years and older, with signs and/or symptoms indicative of possible spinal cord pathology, who had an HIV test done during investigation. Patients excluded were those who had not undergone an HIV test, or who had another recognised aetiology that could better account for symptoms and signs.

The study was approved by the Ethics Committee of the University of Pretoria.

The serology for HTLV-1 detection was performed with ELISA by the NHLS. The spinal cord diameters were measured at level T7 on MRI by a blinded observer who had no access to the patients clinical information. The data was analysed to determine summary statistics and proportions, and the proportions were compared using an independent t-test. Meanwhile, comparison for continuous data was undertaken using $\mathrm{t}$-tests for independent samples. Stata 12 was the software used.

\section{Results}

The records showed 73 patients had positive serology for HTLV-1, of whom 25 were seen at the Department of Neurology with signs of a myelopathy. Of these, 20 were included in the study: 9 tested positive for HIV, and 11 tested negative. Of the 5 patients who were excluded, 4 had alternative aetiologies for their suspected myelopathy: 1 (HIVnegative) was found to have a profound vitamin B12 deficiency, and 3 had spinal tuberculosis. The 5th patient had HAM but had not had not undergone an HIV test.

The clinical data of the patients are presented in Table 1 (HIVnegative patients with HAM) and Table 2 (HIV-positive patients with HAM).

The HIV-negative group consisted of 8 men and 3 women between 21 and 57 years of age, with a mean of $43,7 \pm 8,61$ years. Minimum duration of symptoms was 4 months and maximum 14 years; most patients (7/11) had been symptomatic for 3 years or more. Sphincter disturbances were common, occurring in $8 / 11$ patients $(72 \%)$, and sensory complaints were noted in $9 / 10$. Radiological reports noted atrophy of the cord on MRI in 6 patients, swelling of the cord in

Table 1. Clinical data of HIV-negative patients with HAM

\begin{tabular}{|c|c|c|c|c|c|c|c|}
\hline Number & Sex & $\begin{array}{l}\text { Age } \\
\text { (years) }\end{array}$ & $\begin{array}{l}\text { Duration } \\
\text { (months) }\end{array}$ & $\begin{array}{r}\text { Power } \\
\text { (MRC) }\end{array}$ & $\begin{array}{l}\text { Sphincter } \\
\text { problems }\end{array}$ & $\begin{array}{l}\text { Sensory } \\
\text { symptoms }\end{array}$ & $\begin{array}{l}\text { Cord } \\
(\mathrm{mm})\end{array}$ \\
\hline 1 & $\mathrm{M}$ & 48 & 144 & 2 & $\mathrm{Y}$ & $\mathrm{N}$ & NA \\
\hline 2 & $\mathrm{M}$ & 47 & 48 & 3 & $\mathrm{Y}$ & $\mathrm{Y}$ & 4,4 \\
\hline 3 & $\mathrm{M}$ & 44 & 9 & 3 & $\mathrm{Y}$ & $\mathrm{Y}$ & 9,6 \\
\hline 4 & $\mathrm{M}$ & 43 & 4 & 2 & $\mathrm{~N}$ & NA & 8,8 \\
\hline 5 & $\mathrm{~F}$ & 21 & 12 & 4 & $\mathrm{~N}$ & $\mathrm{Y}$ & 5,1 \\
\hline 6 & $\mathrm{M}$ & 47 & 72 & 4 & $\mathrm{Y}$ & $\mathrm{Y}$ & 4,5 \\
\hline 7 & $\mathrm{~F}$ & 43 & 36 & 3 & $\mathrm{~N}$ & $\mathrm{Y}$ & 3,8 \\
\hline 8 & $\mathrm{M}$ & 51 & 168 & 1 & $\mathrm{Y}$ & $\mathrm{Y}$ & 4,0 \\
\hline 9 & $\mathrm{M}$ & 57 & 36 & 3 & $\mathrm{Y}$ & $\mathrm{Y}$ & 4,2 \\
\hline 10 & $\mathrm{M}$ & 41 & 156 & 4 & $\mathrm{Y}$ & $\mathrm{Y}$ & 5,4 \\
\hline 11 & $\mathrm{~F}$ & 39 & 24 & 3 & $\mathrm{Y}$ & $\mathrm{Y}$ & 4,0 \\
\hline
\end{tabular}

Table 2. Clinical data of HIV-positive patients with HAM

\begin{tabular}{|c|c|c|c|c|c|c|c|c|}
\hline Number & Sex & $\begin{array}{l}\text { Age } \\
\text { (years) }\end{array}$ & $\begin{array}{l}\text { Duration } \\
\text { (months) }\end{array}$ & $\begin{array}{l}\text { Power } \\
\text { (MRC) }\end{array}$ & $\begin{array}{l}\text { Sphincter } \\
\text { problems }\end{array}$ & $\begin{array}{l}\text { Sensory } \\
\text { symptoms }\end{array}$ & $\begin{array}{l}\text { Cord } \\
(\mathbf{m m})\end{array}$ & $\begin{array}{l}\text { CD4 } \\
\times 10^{6} / 1\end{array}$ \\
\hline 1 & $\mathrm{M}$ & 34 & 4 & 3 & $\mathrm{Y}$ & $\mathrm{Y}$ & NA & 5 \\
\hline 2 & M & 42 & 6 & 5 & $\mathrm{Y}$ & $\mathrm{Y}$ & 6,2 & 27 \\
\hline 3 & M & 32 & 5 & 4 & $\mathrm{Y}$ & $\mathrm{N}$ & 6,7 & 31 \\
\hline 4 & $\mathrm{~F}$ & 36 & 96 & 4 & $\mathrm{Y}$ & $\mathrm{N}$ & 4,3 & 300 \\
\hline 5 & $\mathrm{~F}$ & 25 & 11 & 4 & $\mathrm{Y}$ & NA & 4,4 & 484 \\
\hline 6 & M & 36 & 3 & 3 & $\mathrm{Y}$ & $\mathrm{Y}$ & 5,7 & 148 \\
\hline 7 & $\mathrm{~F}$ & 45 & 36 & 4 & $\mathrm{Y}$ & $\mathrm{Y}$ & 4,1 & 1076 \\
\hline 8 & $\mathrm{~F}$ & 31 & 24 & 2 & $\mathrm{Y}$ & $\mathrm{Y}$ & 2,9 & 635 \\
\hline 9 & $\mathrm{~F}$ & 49 & 96 & 2 & $\mathrm{Y}$ & $\mathrm{Y}$ & 5,1 & 580 \\
\hline
\end{tabular}




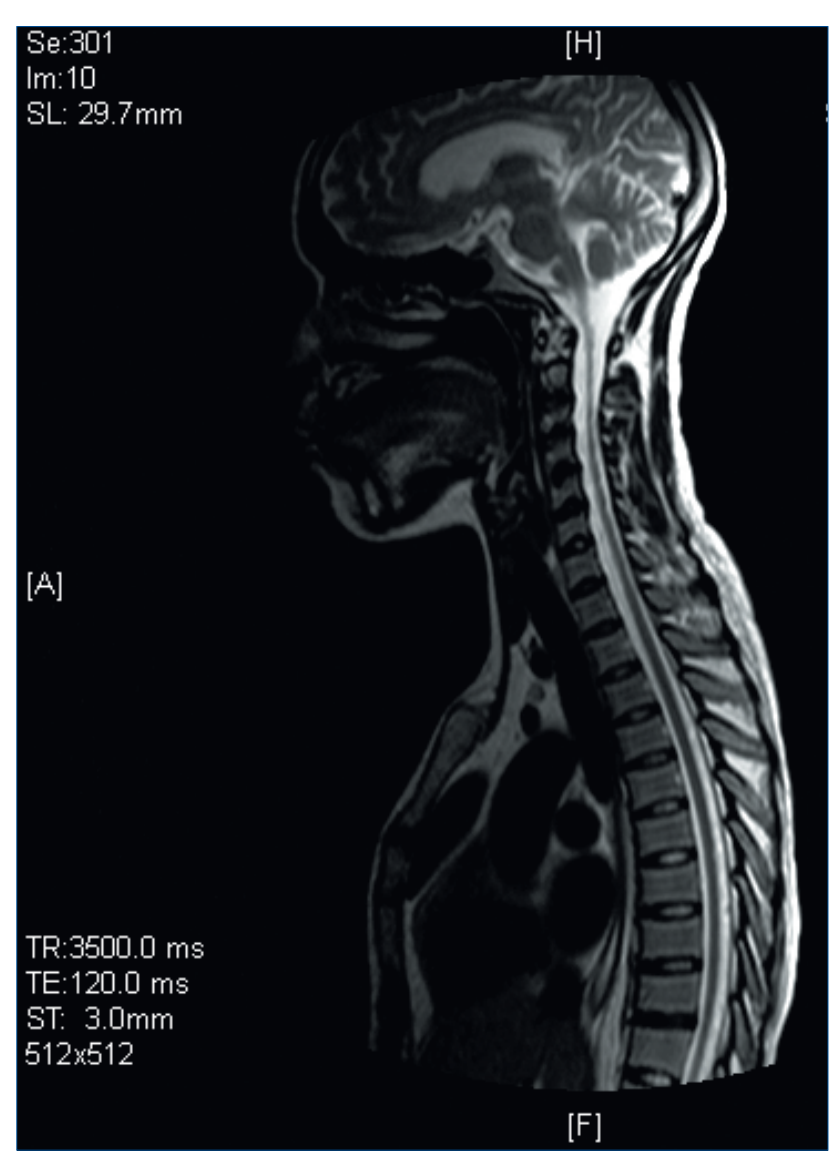

Fig. 1 MRI of patient 5 of the HIV-positive group to illustrate typical thoracic cord atrophy. The cord measured $4,4 \mathrm{~mm}$ at the T7 level.

one and evidence of possible transverse myelitis in one. A blinded observer measured cord diameter at level T7, yielding values ranging from $3.8 \mathrm{~mm}$ to $9.6 \mathrm{~mm}$ (normal: $6.5 \mathrm{~mm}-9.5 \mathrm{~mm}$ ), with a mean of $5.4 \mathrm{~mm}$. Values $<5 \mathrm{~mm}$, implying severe atrophy, were measured in $60 \%$ of patients.

Five females and four males were seen in the HIV-positive group. Their ages ranged from 25 to 49 years with a mean of $36.6 \pm 7.06$ years, but though this was lower than in the HIV-negative group, no evidence of a statistically significant difference with respect to age could be demonstrated. Symptoms had been present for 3 months to 8 years, with $66 \%$ of patients symptomatic for less than 3 years. Sphincter disturbances were present in all patients, and $75 \%$ had sensory complaints. A trend towards statistical significance $(\mathrm{p}<0.055)$ between patients $<40$ years old and $>40$ years old was observed in proportion to sensory symptoms: all older patients had sensory symptoms, compared with half of the younger ones.

Patients' CD 4 counts ranged from 5 to $1076 \times 10^{6} / 1$, while $56 \%$ had counts of less than $350 \times 10^{6} / 1$. Two patients were on highly active antiretroviral therapy (HAART) at presentation. Atrophy of the cord was reported on MRI studies in 4 patients, and a transverse myelitis picture in 1 . When the thoracic cord was measured at level $\mathrm{T} 7$, the values ranged from $2.9 \mathrm{~mm}$ to $6.7 \mathrm{~mm}$ (mean: $4.9 \mathrm{~mm}$ ). Thus, 7/8 patients had cord atrophy, and values of $<5 \mathrm{~mm}$ were seen in $50 \%$ of patients (see Fig 1). There was no evidence of statistical difference in the proportion of patients with cord atrophy in the HIV-positive v. the HIV-negative group.

\section{Discussion}

HTLV-associated myelopathy was first described in the 1950s in the Caribbean, ${ }^{7}$ but it was only in 1985 that the condition was linked with antibodies to the retrovirus known as HTLV. ${ }^{8}$ HAM is a progressive neurodegenerative disease that primarily affects the spinal cord and brain. Risk factors for developing an HTLV-associated myelopathy are the same as those for the transmission of HIV, including younger age of initiation of sexual intercourse and multiple sexual partners. ${ }^{9}$

Patients present with a slowly progressive paraparesis affecting the lower limbs ${ }^{10}$ with a cumulative risk of $1.7 \%$ of developing HAM by the age of 75 years if infected with the virus. ${ }^{11}$ Other clinical features include lumbar pain, detrusor instability, and minor sensory changes, especially paraesthesias and loss of vibration sense..$^{12}$ In our study, the patients singly infected with HTLV showed a disease progression and clinical signs and symptoms in keeping with this classic description.

Our study showed that co-infected patients had a more rapid progression of symptoms that led to an earlier hospital visit. The duration of symptoms in more than half of our patients was less than a year - a finding not documented in other studies. The clinical picture in the dually infected patients may reflect virus-virus interaction. ${ }^{13}$ Dually infected patients have higher levels of HTLV antigen and tax/ rex RNA expression in peripheral blood mononuclear cells, thereby up-regulating HTLV viral message and portending HTLV-associated neurological disease. ${ }^{14}$

Patients in a previous study by Beilke et al. ${ }^{15}$ had high CD 4 counts, ranging from $890-1613 \times 10^{6} / 1$. However, our study shows that HAM can occur at any stage of immune suppression: CD 4 counts ranged from 5 to $1076 \times 10^{6} / 1$, and most of our patients had CD 4 counts of less than $350 \times 10^{6} / 1$. It is unlikely that any of the patients had HIV-associated vacuolar myelopathy since the characteristic lesions (hyperintensities in the posterior and lateral columns) were not noted on MRI. About half of all patients with HAM currently seen at the Steve Biko Academic Hospital are infected with HIV, compared with $33 \%$ in KwaZulu-Natal. ${ }^{5}$ Co-infection of HTLV-1 and HIV in patients with HAM has been mentioned in several studies. ${ }^{4,5,14,15}$ According to Berger et al., ${ }^{16}$ patients co-infected with HIV/HTLV are at increased risk for developing HAM. Elsewhere, a Brazilian study compared the clinical evidence of a myelopathy in 32 co-infected patients (HIV/ HTLV) with 118 patients singly infected with HIV, and found a higher incidence of signs of myelopathy in co-infected patients. ${ }^{4}$

Bhigjee et al. previously found a co-infection rate of HIV and HTLV-1 in $6 \%-8 \%$ of patients with HAM. In a study on the spectrum of myelopathies in HIV positive patients in South Africa, ${ }^{5}$ they found that $33 \%$ of patients had seropositivity for both HIV and HTLV-1, suggesting a higher frequency of myelopathy in co-infected patients. In addition, the patients were younger than those without HIV infection, but otherwise similar, without profound immunosuppression.

Although the findings did not reach statistical significance, the tendency for HIV-positive patients to be symptomatic from HAM at a younger age is also suggested in our study, where 6/9 co-infected patients were younger than 40 years and only $2 / 11$ patients under the age of 40 were singly infected with HTLV. A retrospective study from Louisiana ${ }^{15}$ evaluated HTLV 1 and 2 infection in HIV-positive patients, identifying 5 patients with HAM and HTLV-1 infection whose clinical findings were described, but not specifically compared with those of HIV-negative patients with HAM from the same unit. The patients' ages ranged from 27 - 51 years, with 3 younger than 40 years.

The reported incidence of cord atrophy in HAM varies from $5.6 \%$ to $74 \% .{ }^{17-18}$ Cord swelling may also occur, possibly in the earlier stages of disease. ${ }^{19}$ Measurements of the thoracic cord diameter in our patients showed that $80 \%$ of the HIV-negative group and $88 \%$ from the HIV-positive group showed atrophy of the cord on MRI - more than currently indicated in the literature. In addition to spinal cord abnormalities, white matter 


\section{RESEARCH}

lesions in the brain have also been described in individuals with HAM..$^{20}$ Only 3 of our 9 co-infected patients underwent brain imaging, but cerebral atrophy occurred in all 3, possibly reflecting the longstanding HIV infection. Only 1 showed white matter involvement.

\section{Conclusion}

We found that patients co-infected with HIV and HTLV tended to have a younger age of onset, an earlier presentation to hospital and universal sphincter involvement, and commonly had evidence of spinal cord atrophy. In addition, when compared with other cases with dual infection described in the literature, our patients had a wide range of CD4 counts, indicating that HAM in HIV-positive patients may occur in cases of profound immunosuppression as well as early in the course of infection. The study is limited by the small number of patients assessed, and more data need to be collected to show possible statistical differences.

\section{References}

1. Manns A, Blattner WA. The epidemiology of the human T-cell lymphotrophic virus type I and type II: etiologic role in human disease. Transfusion 1991;31(1):67-75

2. Cabre P, Smadja A, Cabié A, Newton CRJC. Neurological aspects of tropical disease: HTLV-1 and HIV infections of the central nervous system in tropical areas. J Neurol Neurosurg Psychiatry 2000;68:550557. [http://dx.doi.org/10.1136/jnnp.68.5.550]

3. Price RW. Neurological complications of HIV infections. Lancet 1996:348(9025):445-452.

4. Harrison CH, Vaz B, Taveira DM, et al. Myelopathy among Brazilians co-infected with human T-cell lymphotropic virus type I and HIV. Neurology 1997;48(1):13-18.

5. Bhigjee AI, Madurai S, Bill PL, et al. Spectrum of myelopathies in HIV seropositive South African patients. Neurology 2001;57(2):348-351.
6. Medical Research Council. Aids to the Examination of the Peripheral Nervous System. London: Her Majesty's Stationery Office, 1981

Cruickshank EK A neuropathic syndrome of uncertain origin; review of 100 cases. West Indian Med J 1956;5(3):147-158

Gessain A, Barin F, Vernant IC, et al. Antibodies to human T-lymphotropic virus type-I in patients with tropical spastic paraparesis. Lancet 1985;2(8452):407-409.

9. Krämer A, Maloney EM, Morgan OS, et al. Risk factors and cofactors for human T-cell lymphotropic virus type I (HTLV-I)-associated myelopathy/tropical spastic paraparesis (HAM/TSP) in Jamaica. Am J Epidemiol 1995;142(11):1212-121

10. Nakagawa M, Izumo S, Ijichi S, et al. HTLV-1 associated myelopathy: analysis of 213 patients based on clinical features and laboratory findings. J Neurovirol 1995;1:50-61.

11. Maloney EM, Cleghorn FR, Morgan OS, et al. Incidence of HTLV-1-associated myelopathy/tropical spastic paraparesis (HAM/TSP) in Jamaica and Trinidad. J Acquir Immune Defic Syndr Hum Retrovirol 1998;17(2):167-170

12. Castro NM, Rodrigues $\mathrm{W}$ Jr, Freitas DM, et al. Urinary symptoms associated with human T-cell lymphotropic virus type I infection: Evidence of urinary manifestations in large group of HTLV-I carriers. Urology 2007;69(5):813-818.

13. Berger JR, Svenningsson A, Raffanti S, Resnick L. Tropical spastic paraparesis-like illness occurring in a patient dually infected with HIV and HTLV-II. Neurology 1991;41(1):85-87. [http://dx.doi. org/10.1212/WNL.41.1.85

14. Beilke MA, Japa S, Vinson D. HTLV-I and HTLV-II virus expression increase with HIV-1 co-infection Journal Aquir Immune Defic Syndr Hum Retrovirol 1997;17(5):391-397.

15. Beilke MA, Japa S, Moeller-Hadi C, Martin-Schild M. Tropical spastic paraparesis/ Human T leukemi virus type 1-associated myelopathy in HIV type 1 co-infected patients. Clin Infec Dis 2005;41:57-63. [http://dx.doi.org/10.1086/432890]

16. Berger JR, Raffanti S, Svenningsson A, McCarthy M, Snodgrass S, Resnick L. The role of HTLV in HIV 1 neurologic disease. Neurology 1991;41(2 pt 1):197-202.

17. Milagres AC, Jorge ML, Marchiori PE, Segurado AA. Human T-cell lymphotropic virus type 1-associated myelopathy in Sao-Paulo, Brazil. Epidemiologic and clinical features of a university hospital cohort. Neuroepidemiology 2002;21(3):153-158.

18. Ferraz AC, Gabbai AA, Abdala N, Nogueira RG. Magnetic resonance in HTLV-1 associated myelopathy: leukoencephalopathy and spinal cord atrophy. Arq Neuropsiquiatr 1997;55(4):728-736.

19. Shakudo M, Inoue Y, Tsutada T. HTLV 1 associated myelopathy: Acute progression and atypical MR findings. Am J Neuroradiol 1999;20:1417-1421.

20. Bagnato $\mathrm{F}$, Butman JA, Mora CA, et al. Conventional magnetic resonance imaging features in patients with tropical spastic paraparesis. J Neurovirol 2005;11(6):525-534.

Accepted 12 September 2012 